\title{
Participation on the Margins of Immigrant Women's Lives and Learnings
}

\author{
SONDRA CUBAN
}

\begin{abstract}
This study focuses on the participation and learning of five women immigrants in the Northwest US and the ways community-based organisations (CBOs) operated in their work and community lives. The study points to the ways that the women became assertive at work, moved from the private into the public sphere, and developed caring literacies in their communities.
\end{abstract}

\section{Introduction}

A paucity of research exists on the roles of community-based education programs in the lives of women in 'borderlands' (Anzaldua1990). As undocumented immigrants, they can access these learning sites, but are prohibited from using others due to recent anti-immigrant legislation. This study focuses on the accommodating ways CBOs sponsor marginalised groups, rather than colleges which are bound to an 'enrolment economy' (Rockhill 1982); or as one director of a CBO described, a 'punch clock'. CBOs and their community-based education programs are also more accommodating than typical English to Speakers of Other Languages (ESOL) workplace programs, which tend to follow the employers' agendas for upgrading literacy skills, overlooking the authentic needs of learners/workers (Gallo 2004). Learners are expected to enter both types of programs in order to fulfill targeted learning tasks and then leave when these are done, as if they were in a factory job. Their participation is valued in terms of shift work especially when they perform according to 'time on task'. Their learning is inspected through an 'edumometer' (a standardised assessment that measures educational performance) which is one of many technologies of power that control learners (Corbett 2008). The logic underpinning these practices supports the 'science of economics' that is endemic to neo-liberal pedagogy focused on individualism, efficiency and production (Giroux 2008:65). In taking federal funding, programs implement policies that surreptitiously exclude learners, such as undocumented immigrants who cannot comply with these new standards. CBOs, however, operate according to a different logic.

Five undocumented Mexican domestic workers sporadically attended three CBO programs on the west coast of the US They persisted in their 
literacy and language learning, even when they were not formally enrolled. Furthermore, they were viewed as members of the community and learners in their programs, even when they had not shown up for a long time. This view contradicts conventional knowledge of participation as a regulated, uninterrupted pathway (Porter, Cuban and Comings 2005).

\section{ESOL participation and learning in the United States}

With the burgeoning ESOL population in most advanced economies' adult basic education systems, there has been increased interest in their participation and learning. Although ESOL learners' growing presence is acknowledged, they are largely 'overlooked and understudied' (MathewsAydinli 2008:201). Program factors are critical. Prospective students and participants now endure waiting lists, fees, and a back-to-basics vocationalist curriculum; for example, a study, Lost in Translation (Colton 2006), found that the adult basic education system is nearly collapsing under the weight of demand in New York State and ESOL learners' needs are unmet.

ESOL learners are often represented as strong participators, able to overcome numerous hurdles to attend (Comings, Parrella and Soricone 1999). Some studies have examined these obstacles, particularly for immigrant and refugee women. They point to previous traumatic experiences like war, which make it difficult to learn, retain information, and concentrate (Isserlis 2000). Additionally, immigrant women often face discrimination in the workplace as well as violence at home (Rockhill, 1990, Norton 2000), which prevent them from attending programs. These studies point to how programs often do not compensate for these gendered/raced barriers, nor do they match the perceptions that these learners have of progress, which are different from the test score gains that are commonly emphasised by policymakers and program administrators (Mathews-Aydinli 2008).

There has been little attention paid to the complex ways that ESOL women learners learn a new language and use literacy within their networks, including their strategies and resources for overcoming problems and advancing. Much of this is due to the nature of participation research, which either makes these learners invisible or passive recipients of services in a restrictive system (Isserlis 2008). Rockhill (1982:3) shows that participation research is problematic because of its 'superimposed definitions and its valueladen constructs'. Studies typically disregard learners' activities in other domains apart from formal education, and if they are not actively enrolled in a legitimate learning site, they are considered, 'non-participants'. Moreover, 'non-participant' translates to 'non-learner' (Cuban 2006). Although policy makers now recognise that students tend to stop out rather than drop out (Belzer 1998, Tolbert 2005), this concept is rarely incorporated into 
programs that are primed to meet targets, and those who do not follow this logic, like CBOs, are excluded. Finally, immigrant women, as a valid category, is unavailable in national data sets, and without it, their active participation is unknown in programs or policies.

Curriculum is another problem in mainstream programs because often it does not match learners' literacy and language interests and needs. Commercial ESOL texts quite frequently do not confront real-life problems of women immigrants such as the "unhealthy living and working conditions, crowded clinics, high costs...which neither prepare students for what they might encounter nor legitimate these experiences when students do encounter them' (Buttaro and King 2001:55-56). Furthermore, a complex sense of belonging and identity is absent in curricula that emphasise women immigrants adapting to societal norms. Curriculum standards that focus on conventional topics and individual skill sets assume women immigrant learners (and potential learners) can tackle these problems alone.

\section{A gendered social practice framework for analysing women immigrants' literacies and language practices}

A gendered social practice approach highlights the barriers in formalised programs (like curriculum and program structures previously mentioned), while also paying attention to the literacy and learning strategies and resources women immigrants draw on outside these learning sites, for example, in CBOs, workplaces and communities. Using a gendered social practice perspective (Norton 2000, Robinson-Pant 2004, Moss 2007, Cuban forthcoming), I show that the views of immigrant women learners and staff in CBOs, on learning, persistence, and literacies, were outside the dominant lens of participation, outlined above. Their own framings, and validation as learners, with their own interests, re-located them into an accepting environment, far from the displacement and estrangement they experienced in other institutions. The CBOs offered the women, 'just-in-time' resources to negotiate new identities outside their difficult work conditions (Louie 2001), building on their literacies and language assets and strategies in ways that were unavailable in formal programs. The immigrant women in this study struggled for self-determination with $\mathrm{CBOs}$, which were part of their social networks.

The CBO staff acted as literacy and language sponsors (Brandt 2001) who were attuned to the women's issues and interests and created informal opportunities for them to advance. While these 'third sector' agencies are not immune from co-option by mainstream policies and programs whose sponsorship is through recruiting, regulating or withholding literacy (Brandt 2001), CBOs enable and support women immigrants to build networks outside enterprise models (Mojab and Gorman 2003). 
This sponsorship is especially important for undocumented Latina learners, who may feel unsafe and insecure, due to their lack of protection, and have few agencies promoting their interests. CBOs more than compensate for this population, however, and aim for self-organising. Because of their central physical location in communities, partnerships with other organisations, and their specialisation in learners' local/indigenous knowledge bases, and languages (through bilingual and participatory methods), they have a deep understanding of the diverse issues they face on a daily basis and can address their real-life problems and practices (Rivera and Huerta-Macias 2008). The staff can also help learners learn new practices so they can develop solutions to their problems, and they nurture their leadership and expertise, similar to what bell hooks (in Belenky, Bond and Weinstock 1991), calls 'home places'. These places are nested within the community, are effective in creating loosely formed and culturally relevant networks, and in providing supports to particular women on an as needed basis. The 'home place' metaphor is significant because the workplaces of the women were in private homes that were anything but accommodating. The programs were like havens and public niches that marked them as different from the private spaces of the homes they cleaned and lived in, which were hazardous (due to employer and partner abuse). They also were places to network and develop innovative strategies for gaining more resources and changing practices.

One example of a CBO that models these issues is Casa Latina. In 2005, participants in its women's leadership program, through discussions and analysis, led an opposition to an ID Act, because it would limit their abilities to obtain drivers' licenses and be detrimental to their autonomy and ability to engage in domestic work. Casa Latina has a multi-issue women's group focusing on domestic violence and other problems, as well as a domestic work group. These groups, led in Spanish by learners, are designed specifically to give support and information. Over the years, staff have acted as spokespersons to develop immigrant rights dialogues about organisational change to meet community needs (Stern 1998).

Instead of employing top-down policy logic ('time on task') for recruiting learners who can demonstrate short-term gains, Casa Latina, operates according to (in drawing from Anzaldua's ideas) 'borderland logic' (Cuban this volume). They recognise the women's hardships as well as their literacy and language resources, and maximise their networking opportunities with supportive, culturally-based, and gender-sensitive services. One coordinator (Fachinelli, personal conversation 2008) says of the women's leadership program, it operates according to 'the power of connection and networking, through the meetings, and providing space, providing 
connection.... We would proceed with their needs, combine and give them space to be and work together'.

\section{The study: methods and focus}

Five women immigrants were interviewed at different points between 2000-2005 in two cities in California and Washington. I contacted the women through CBO program staff who were also interviewed. Program observations were made for several days, every six months, over a three-year period in the California site. In Washington, several observations were made in one of the programs during a two-year period, in order to supplement the data gained from graduate education student research in both sites. I also served as an advisory member, in a faculty capacity, to one of the organisations, which allowed me to gain access to it. In the other organisation, contacts through a popular education network were made.

Each of the women learners was interviewed with a loosely structured interview that lasted between one and two hours, and one woman was interviewed twice. The interviews were conducted in homes, cafes, and afterschool spaces - places the women selected that allowed them to feel safe to talk. The interviews were comprehensive so as to focus on their learning across many domains/contexts of their lives. Questions were asked about their biographies, their work, their learning, their literacy practices, and their persistence in educational and learning activities and practices inside and outside of the programs to understand what they gained from their experiences. After each woman was interviewed, a transcript or a transcript summary was created from the tape recording, after which it was read and reread, then, through an iterative process of memoing, interpreting, and analysing, profiles were developed. These profiles were cross-compared with others to generate larger themes about the interactions between CBOs and women immigrants, and their participation, literacy, and learning practices in the larger context of social and educational policies (Denzin 1989, Siedman 1998). The interpretative approach focuses on highlighting a narrative about the underlying meanings of a phenomenon within society. It is a layered process that allows for a concept, that would normally lie dormant beneath policy talk, to be highlighted and focused on intensely in a profile - in this case, the women's informal learning, language, and literacy practices.

The women had similar demographic traits, as Mexican undocumented domestic workers, and their profiles revealed unique trajectories that did not fit formalised program profiles:

- Elly, in her early 40 s, was a former nurse, who was married, with two young boys. Because of childcare and transportation limitations, her 
tutoring took place in her small caravan, where she studied nursing texts with her tutor and on her own. After a third pregnancy, she stopped, but kept in touch with her program.

- Emelia, 28, was a mother of two young children who lived in a onebedroom apartment with her husband. She cleaned houses every day and then from 3 o'clock onwards, was with her children and her 'best friend' the TV, because she learnt English while watching it. She left the program temporarily, because she was too busy, and every so often borrowed books and videos for her children at the library.

- Estrella, 44, a former waitress in Mexico, had a six year old, and was married to a diabetic husband. She attended a small group at her local school, in between her visits with him to the hospital. She wanted to develop her career in the US and sought out a community health program where she became a neighborhood health educator using bilingual education.

- Gloria, 48 , and the mother of a teenager and a 30 year old, had been a nurse in Mexico. She decided to clean after attending a care assistant program and learning that being a care assistant would pay her less money. She had much help for learning English literacy from her son and male friends.

- Mia, 35, had been a cleaner in Mexico and continued with this work in the US, although she wanted to be a social worker/community worker. She was the mother of four teenagers, one of whom was suicidal. Through seeking help for her daughter, she learned about community programs, which she attended. She originally attended a program to practise English conversation and eventually facilitated a group on domestic abuse, knowing about it from first-hand experience.

The program staff consisted of women who were part of the learners' communities and knew them well, collaborated with social organisations for support services, and advocated for immigrant rights. They also empathised with the women participants' issues and were close to many of them. One staff member, for example, was a long-standing community advocate, networking with many agencies for immigrant services and saw immigrant students as the 'invisibles' who were not getting adequate help. Her staff knew the students well and saw it as their main role to meet their needs, irrespective of whether or not they fell within the official remit of the program. They also called the students when they had not showed up and refused to see them as 'drop outs'.

The programs drew on a combination of learner-centered and labor education approaches that emphasised unconditional respect for and accommodation of the learners' needs (whatever they were), especially their 
work lives. This approach was vital for women who were in jobs that were considered to be dirty and degrading (discussed in the thematic section), not to mention, isolating. The goal was to foster their outside connections, through fusing with other community organisations, and through networking the women with one another, and with other agencies, in order to learn and build on their capacity to make change.

The staff did not refer to learners as having literacy skill deficits, nor did they use conventional labels for them, also tutors were referred to as colearners. Homework was not given because of the academic and child-like connotations and because the women had little time to do it. The staff offered flexible entry/exit options, comprehensive services, multi-modal instruction, incentives, bilingual communication and flexible arrangements, which fitted the women's work and family rhythms. These traits differed from most state-mandated programs that had demanding agendas.

\section{Themes about the women's participation, learning, and literacy practices}

While the women showed considerably diverse learning, participation, and literacy trajectories, there were notable patterns among them. A close look at the women's work situations was important for understanding how the CBOs addressed their learning support needs and informal strategies for literacy and language practices. This section presents those themes, which are not addressed in the literature.

\section{Being Assertive at Work}

The women, all of whom were of color and were limited English speakers, endured numerous exploitative and racist encounters with their employers, mostly middle-class, native-born Caucasian women, whose houses they cleaned. Their need, therefore, was to develop expertise in asserting themselves, in ways that would be understood across race and class boundaries. Not all of their employers, however, were forbidding, and, in a charitable manner, they gave them household items, found them additional jobs, invited them to family events or helped them to learn English.

Nevertheless, exploitation was rife.

The homes were all large and it took the women hours to clean them. Yet they were often rushed, were told they could not take breaks, make phone calls, or drink water, even when they were ill. These employers would use humiliating tactics to degrade the women, such as asking them to wash the floors on their hands and knees while watching them or watching the clock, refusing to pay, asking them to work overtime without pay, or, leave cheques under the welcome mat refusing to rewrite them when they were wet 
and illegible. Mia told a story about a 'boss' who told her she 'had a job because of the $\mathrm{dog}^{\prime}$ and would not put the dog on a leash even though Mia told her employer she was scared of it. After Mia facilitated a program group on abuse, in Spanish, where she observed that the other women didn't see their husbands' hitting them as abuse, Mia realised that she was being abused by her employer. One of Mia's problems was asserting herself orally with her employers, so she listened to English language radio and TV to help her practise interacting with them. She also had problems reading the notes that they left for her. But she got help from one of the CBO staff, as well as her daughter and a friend who was in women's studies at the local university. On Saturdays, they would sometimes go with Mia to the houses and translate texts and conversations.

The women's learning of English in the CBOs paid off in poignant ways. Once Mia developed confidence in using English conversationally, she would listen and give advice to the children of her employers, which made her realise she wanted to work with teens in the future. She would tell the parents about their children's problems and attempt to mediate between them, building a stronger base of support for herself in their home. Yet, it wasn't without problems. She said, 'Kids will open to you and will tell you everything. I tell them [the parents] and they think I am crazy. They don't appreciate this. They don't like that [but] they stop it [their behaviours]'. While she was able to communicate with these teens, she had a difficult time communicating with her troubled daughter at home, and she sought out more opportunities to learn about the emotional needs of adolescents. The women's informal learning at work was critical to their ability to communicate effectively. The program encouraged this in ways similar to those Romero (1992) has documented, that is, the ways that domestic workers keep employers at bay by using assertive communication tactics.

\section{Moving from the private to the public}

The women came to the $\mathrm{CBO}$ s when events in their lives were more stable, and they stopped when major events disrupted it, especially illnesses, childcare and pregnancies. They felt attached to the CBOs because they knew they could come back any time, and were invited and welcomed. Elly for example, in a follow-up interview, said that she was 'taking a break for one month, because she had surgery, and [I] told my tutor I wasn't feeling well, and would return'. Elly studied nursing texts with her tutor who translated difficult concepts from English to Spanish. Elly felt he was a 'brother' to her. She also practised English with him on the library computer. She appreciated his accommodation of her emotional states, and she would let him know that she was not feeling well, and didn't want to study: 'But I say sorry Leonard...maybe my brain today's don't work and he tell me its ok its ok take 
care relax maybe another time.'This flexibility was different from the local college where she recalled, 'because some days I don't feel good, and I don't went to the school. The day doesn't return. The lesson doesn't repeat. This was very difficult for me'. She felt she didn't want to keep cleaning houses because the chemicals caused rashes on her body but she felt that she had to do this to survive. Still, reading nursing texts helped to keep her 'big, big, big dream' alive of being a nurse in the US and gave her the impetus to keep learning. Similarly, Gloria's dream was to be a nurse in the US like she was in Mexico, and she went to the community college to seek out information about it. But when she was held up by a series of pre-requisite courses in order to convert her credentials, she realised how long it would take and at a loss of wages. She then decided, through the support of various friends, and the program, to fully engage in her cleaning business, and establish relations with her various employers to network and build her social capital. One of her employers, invited her to her daughter's wedding, which, while not unproblematic, led to new networks:

When I came to the party, I feel good. But everyone is staring...I see I am the only Hispanic people. I start talking with two bosses, and we are laughing and my boss, because we speak Spanish, she sit with me a woman. Later the person [her boss's husband], take my hand and dance - it's a Jewish dance. I feel good.

In spite of the women's lack of legal rights and available services, the women's programs served as stepping stones to develop a public personae and networks that emerged from the privacy of the homes where they worked.

\section{Spreading caring literacies into communities}

The women had helpers who mediated between their communities and the fast capital texts they encountered in their workplaces and in other institutions (Lu 2007). These helpers are discussed in the literature in clinical terms, such as, 'brokers', 'mediators', 'connectors', or 'readers', with the taskspecific nature of the literacy assistance emphasised. The relational aspects, however, are overshadowed by the acts themselves. Often, receivers of literacy help, in the literature, are shown as reciprocating through a nonliterate exchange, and they don't learn from the transaction, nor pass on what they learn. In this sense, they are represented as passive subjects of literacy assistance, while the giver is the one who is empowered. The women in this study, however, constructed themselves as active agents of help, for when they received literacy and language assistance, they felt obliged to help another person with a similar problem, especially within the networks of the CBOs. 
In other words, the textual and language relationships that developed as a result of network members helping one another, and the CBOs building on them, can be called, caring literacies because they went beyond the taskspecific activity (or a literacy event), and bonded a community, through an ethic of care (Tronto 1993). They spread their help as part of broader literacy and language practices and benefits. This type of caring is more sustainable than the patronising maternal behaviours displayed by teachers in mainstream classrooms (Luttrell 1996). Caring literacies come from within the community and are critical to the emotional and cultural bonds and landscape that already exist. The help, which is hands-on, stems from a caring orientation and a desire to support another person, rather than solely from a lone literacy task that needs to be accomplished. Caring literacies are passed on through informal learning and sharing, and they are socio-emotional resources that may be invisible to outsiders to that community. They aim towards collective and individual empowerment, which are not conducive to institutionalised environments, but which blossom in CBOs through established networks.

One example illustrates caring literacies. Estrella's attendance at her small group enabled her to grasp grammar skills in written and oral/aural English. She was assisted by her tutor, who taught in Spanish and English, and the program which provided childcare, freed her up to learn. Like the other women, she also used her local library to get videos and books for her children, in English and Spanish, while using the TV as another media to learn, in addition to computer programs at home. Estrella also decided to get more involved in her child's school, and became a Spanish tutor, after discussing it with one of the teachers who spoke Spanish and thought Estrella would be good at it. Feeling more confident, she left her community more often, taking a computer course at a local centre, during which time she saw a sign advertising peer-health educator program for families. She applied along with her husband, and got a job teaching her neighbours about HIV. She felt that her neighbours weren't as politicised as herself and needed to understand more than survival. Estrella said, 'my people need information for progress, and this very difficult. It's good [tol clean house, but my aspiration is more... I like more -- I work with the people. Because they need much more -- much help’.

\section{Conclusion}

These themes demonstrate the agency, power, and strategies women immigrants exert for learning in spite of tremendous obstacles, and for a sense of collective power. Their consciousness was raised as they interacted with other learners and staff about their work and home lives, and they realised they weren't alone with their problems. While their programs made 
small interventions in the women's lives, it was difficult for them to overturn the larger forces. Cathy Kell (2008) has shown that often, women may start and stop many times under adverse conditions, to speak up and voice their opinions in communities. The women in this study relied on multi-lingual support networks, of which the programs were a part, to sustain their aspirational identities and to engage in their work and communities in more meaningful ways. Their networking naturally enhanced their resources, which were unavailable in mainstream program structures and curricula. These strategies helped to reduce the level of exploitation they experienced at work, but did not eradicate it because larger policies were not in place to enforce them. Gender-sensitive education (Walters 1996, Norton 2000) can assist immigrant women to re-embody themselves as self-possessed actors who achieve small ends each day by struggling to practise literacy and languages in their daily lives. Furthermore, gender-sensitive policies can assist them to map their futures, through mobilising critical resources and supportive networks.

\section{References}

Anzaldua, G (1990) La Conciencia De La Mestiza: Towards A New Consciousness, in Anzaldua, G, ed, Making Face, Making SoulHaciendo Caras, Aunt Lute Foundation Books, San Francisco, CA, pp 377-389.

Belenky, M, Bond, L and Weinstock, J (1991) A Tradition that has No

Name, Basic Books, New York.

Belzer, A (1998) Stopping Out Not Dropping Out, Focus on Basics, vol 2, issue A, retrieved on 7 July 2008 from http://www.ncsall.net/?id=417

Brandt, D (2001) Literacy in American Lives, Cambridge University Press, Cambridge.

Buttaro, L and King, K (2001) Understanding Adult ESL Learners, Adult Basic Education vol 2, no 1, pp 40-60.

Colton, T (2006) Lost in Translation, Center for an Urban Future, New York.

Comings, J, Parrella, A and Soricone, L (1999) Persistence Among Adult Basic Education Students, National Center for the Study of Adult Learning and Literacy, Cambridge.

Corbett, M (2008) The Edumometer: The commodification of learning from Galton to the PISA, Journal of Critical Education Policy, vol 6, no 1, retrieved 7 July 2008 from

http://www.jceps.com/index.php?pageID=article\&articleID=125 
Cuban, S (2006) A Social Practice View of Literacy Vs. a Policy View,

Seminar in Linguistics, June 22 2006, at Universitat Pompeu Fabra,

Barcelona. Retrieved on 12/10/09 at:

http://www.upf.edu/dtf/recerca/grups/grael/LC/smnrs/SC/ALR2.pdf

Cuban, S (forthcoming). Destablilising Gendered Communication in

Workplace ESOL Education, International Review of Education.

Denzin, N (1989) Interpretative Interactionism, Sage, London.

Gallo, M (2004) Reading the World of Work, Krieger, Malabar FL.

Giroux, H (2008) Against the Terror of Neoliberalism, Paradigm Publishers, Boulder.

Isserlis, J (2002). Trauma and the Adult English Language Learner, ERIC

Digest. ED444397, retrieved 27 August, 2007 from

http://www.ericdigests.org/2001-2/trauma.htm.

Isserlis, J (2008) Adults in Programs for the 'Academically Unprepared', New

Directions for Adult and Continuing Education, vol 2008, issue 120, pp 19-26.

Kell, C (2008) Presentation to the Literacy Research Discussion Group, October 20 2008, Lancaster University, UK.

Louie, M (2001) Sweatshop Warriors: Immigrant women workers take on the global factory, South End Press, New York.

Lu, M (2007) Afterword: Reading literacy research against the grain of fast capitalism, in Daniell, B and Mortensen, P, eds, Women and Literacy, Lawrence Erlbaum, Mahwah, New Jersey, pp 297-318.

Luttrell, W (1996) Taking Care of Literacy: One feminist critique, Educational Policy, vol. 10, no. 3, pp 342-365.

Mathews-Aydinli, J (2008) Overlooked and Understudied? A survey of current trends on research in adult English language learners, Adult Education Quarterly, vol 58, no 3, pp 198-213.

Mojab, S and Gorman, R (2003) Women and Consciousness in the Learning Organization, Adult Education Quarterly, vol 53, no 4, pp 228-242.

Moss, G (2007) Literacy and Gender, Routledge, London.

Norton, B (2000) Identity and Language Learning: Gender, ethnicity and educational change, Longman/Pearson Education, Harlow, UK.

Porter, K, Cuban, S and Comings, J (2005) 'One Day I Will Make It': A study of adult student persistence in library literacy programs, MDRC, New York.

Rivera, K and Huerta-Macias, A (2008) Adult Biliteracy: Sociocultural and programmatic responses, Lawrence Erlbaum, Mahwah, New Jersey.

Robinson-Pant, A, ed, (2004) Women, Literacy and Development, Routledge, London.

Rockhill, K (1982) Researching Participation in Adult Education: The potential of the qualitative perspective, Adult Education, vol 33, no 1, pp 3-19. 
Rockhill, K (1990) Literacy as Threat/Desire: Longing to be SOMEBODY, TESL-Talk, vol 20, no 1, pp 89-110.

Romero, M (1992) Maid in the USA, Routledge, New York.

Seidman, I (1998) Interviewing as Qualitative Research: A guide for researchers in education and social sciences, Teacher's College Press, New York.

Stern, H (1998) Dinosaurs and Upstarts: Organizational change at Casa Latina, Focus on Basics, retrieved on 7 July 2008 from http://www.ncsall.net/?id=394

Tolbert, M (2005) Factors Influencing Enrollment and Persistence in Adult Education, Office of Vocational and Adult Education, Washington DC.

Tronto, J (1993) Beyond Gender Difference to a Theory of Care, in Larrabee, M, An Ethic of Care: Feminist and interdisciplinary perspectives, Routledge, New York, pp 240-257.

Walters, S (1996) Gender in Popular Education, Zed, London.

\footnotetext{
${ }^{i}$ Casa Latino Centro de Ayuda Solidaria a los Amigos / Center for Help in Solidarity with Friends. Offers ESOL, workplace learning, and many other services related to workers' rights, and seen nationally as a model of participatory education (see Rivera and Huerta-Macias 2007).
} 
